\title{
Epithelial-mesenchymal transition in prostate cancer: an overview
}

Micaela Montanari ${ }^{1,2}$, Sabrina Rossetti ${ }^{1}$, Carla Cavaliere ${ }^{1,3}$, Carmine D'Aniello ${ }^{1,4}$,
Maria Gabriella Malzone ${ }^{1,5}$, Daniela Vanacore ${ }^{1}$, Rossella Di Franco ${ }^{1,6}$, Elvira La Mantia ${ }^{1,5}$, Gelsomina Iovane ${ }^{1,7}$, Raffaele Piscitelli ${ }^{1}$, Raffaele Muscariello ${ }^{8}$, Massimiliano Berretta ${ }^{9}$, Sisto Perdonà ${ }^{8}$, Paolo Muto ${ }^{6}$, Gerardo Botti ${ }^{5,10}$, Attilio Antonio Montano Bianchi ${ }^{11}$, Bianca Maria Veneziani ${ }^{2}$ and Gaetano Facchini ${ }^{1,7}$

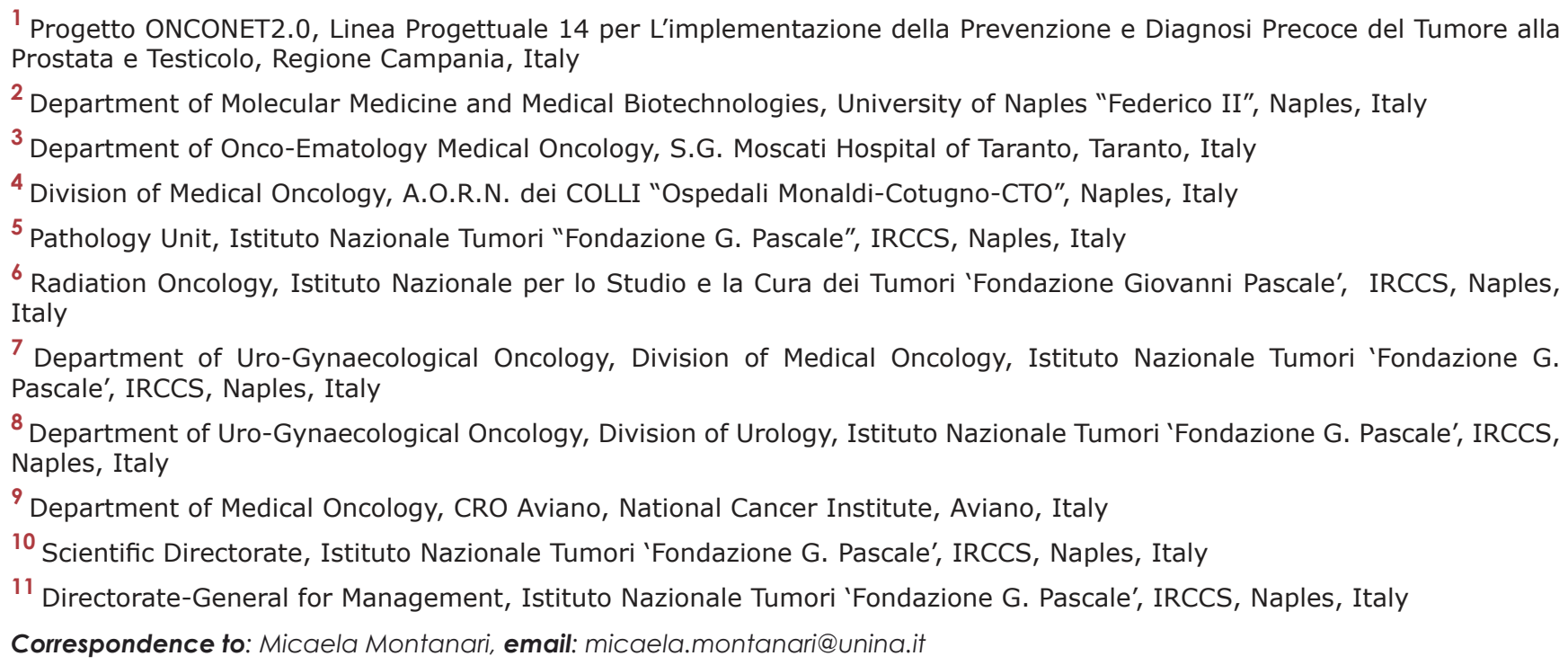
Correspondence to: Micaela Montanari, email: micaela.montanari@unina.it Keywords: prostate cancer; epithelial-mesenchymal transition; androgen receptor; TGF- $\beta$ signaling; EGF/EGFR Received: November 10,2016 Accepted: February 15, $2017 \quad$ Published: February 25, 2017

Copyright: Montanari et al. This is an open-access article distributed under the terms of the Creative Commons Attribution License (CC-BY), which permits unrestricted use, distribution, and reproduction in any medium, provided the original author and source are credited.

\section{ABSTRACT}

Prostate cancer is a main urological disease associated with significant morbidity and mortality. Radical prostatectomy and radiotherapy are potentially curative for localized prostate cancer, while androgen deprivation therapy is the initial systemic therapy for metastatic prostate disease. However, despite temporary response, most patients relapse and evolve into castration resistant cancer.

Epithelial-mesenchymal transition (EMT) is a complex gradual process that occurs during embryonic development and/or tumor progression. During this process, cells lose their epithelial characteristics and acquire mesenchymal features. Increasing evidences indicate that EMT promotes prostate cancer metastatic progression and it is closely correlated with increased stemness and drug resistance.

In this review, we discuss the main molecular events that directly or indirectly govern the EMT program in prostate cancer, in order to better define the role and the mechanisms underlying this process in prostate cancer progression and therapeutic resistance.

\section{INTRODUCTION}

Prostate cancer $(\mathrm{PCa})$ is the second most common cause of cancer-related deaths in male population [1].
Surgery represents a valid tool for the treatment of localized prostate cancer. Nevertheless, nearly all prostate cancer-associated mortality is caused by distant metastasis. The main therapeutic option for advanced prostate tumors 
treatment depends on androgen deprivation therapy (ADT) with limited clinical outcomes. Although the initial response rate is high, the therapeutic benefits are short-lived, and, within 18-24 months, the treated patients progress to metastatic castration-resistant prostate cancer (mCRPC), an androgen-insensitive disease, for which curative therapy is not available [2]. Therefore, the CRPC represents a critical demanding task for the prostate cancer cure. A greater comprehension of the molecular apparatus involved in $\mathrm{PCa}$ distant metastasis formation and metastatic castration-resistance is of critical importance to develop novel therapeutic approaches.

Recently, several evidences of epithelialmesenchymal plasticity playing a role in both $\mathrm{PCa}$ metastatic progression and treatment resistance have been reported $[3,4]$. Epithelial-mesenchymal transition (EMT) has been initially defined as a complex molecular process required during the embryonic development for morphogenetic changes [5]. Therefore, epithelial cells heavily depend on a very fine tuned and highly regulated EMT program, which converts them into a mesenchymal state. Different factors, including microenvironment molecules able to accommodate cellular and tissue growth in normal or altered conditions, along with epithelial and stromal settings, are then required for achieving this program.

Sequential arrangements of adherent junctions, desmosomes and tight junctions allow epithelial cells to be strictly in contact with their immediate environment and also with their axis of polarity. In contrast, mesenchymal cells are loosely structured within a three-dimensional extracellular matrix, which also includes connective tissues [6]. The changes occuring in stroma, together with microenvironment transformation, contributes to create a compartment, where morphological effectors can affect the integrity and vitality of the tissues.

Recently, several articles have been demonstrated the EMT involvement in cancer progression and in metastasis formation, underlining that EMT is a significant event, responsible for triggering metastatic process $[7,8]$. In tumors, local cancer environment epithelial cells must transiently turn into a mesenchymal state for which these neoplastic epithelial cells take over the evolutionary conserved EMT process. Moreover, during EMT the cellular properties (cell-cell adhesion and cell polarity) of polarized epithelial cells are lost while an invasive, well-defined mesenchymal phenotype takes place as a result of multiple important features promoting metastatic development. Coordinated lost and gain of different epithelial ( $\beta$-catenin, E-cadherin) and mesenchymal (vimentin, $\mathrm{N}$-cadherin, fibronectin, and $\alpha$-smooth muscle actin) markers, respectively, enhanced migratory and invasive abilities, increased apoptosis resistance, and extended production of extracellular matrix elements have been shown in human tumor samples and have been correlated to metastatic progression $[9,10]$.
EMT typically occurs at the tumor-stroma interface, due to paracrine signaling molecules [11]. Different pivotal pathways, such as receptor tyrosine kinases, TGF- $\beta$ /canonical and non-canonical SMAD signals, are activated within tumor cells. Importantly, by activating specific transcription factors (e.g. Snail, Twist and Slug), they cause the transcriptional repression of E-cadherin, a defining event in EMT $[9,11]$.

There are considerable data suggesting that EMT contributes to $\mathrm{PCa}$ progression and metastasis. In this review we summarize and discuss the main molecular events that directly or indirectly govern the EMT program in $\mathrm{PCa}$, in order to better define the role and the mechanisms of this process in $\mathrm{PCa}$ progression and therapeutic resistance.

\section{EMT IN PROSTATE CANCER: ROLE OF ANDROGENS AND ANDROGEN- RELATED SIGNALING}

Recently, the importance of EMT in tumor biology has evoked great interest in the scientific audience. Particularly, it has been reported that EMT play a pivotal role in promoting tumor metastasis, conferring cancer stem cell abilities, and mediating drug resistance in several preclinical model of different cancers [12-15], where the expression of EMT related molecules has been found to be well correlated with high grade tumors especially those that have poor prognosis [16].

Recently, many studies have demonstrated the presence of EMT-like states in PCa, suggesting its involvement in prostate cancer development and metastasis $[17,18]$. The main players responsible for EMT in prostate need to be elucidated, and the effect of androgen deprivation therapy on EMT is still unclear.

Prostate is an androgen-dependent tissue that requires androgenic and androgen receptor (AR) signaling axis for normal functioning [19]. Androgens, whose action in adult males promotes the cell survival of secretory epithelial cells (those primarily transformed in tumor development), exert their functions through differential steps consisting of testosterone testicular synthesis, its transport to target tissues, and its reduction to $5 \alpha$-dihydrotestosterone (DHT), mediated by $5 \alpha$-reductase enzyme. Responsible for the physiological growth and development of prostate gland, and for the development and progression of prostate tumors, androgens display their biological activity by binding and consequently activating the androgen receptor (AR) [20]. However, deregulated androgen signaling is one of the most important factors in PCa progression and its pivotal role in modulating androgen-mediated EMT induction has been suggested, even if the mechanistic explanations regarding how the interplay between AR signaling and EMT-related transcription factors expression modulates EMT in $\mathrm{PCa}$, needs to be further investigated. 
Androgens are able to affect EMT of PCa epithelial cells. Here, they suppress the expression of E-cadherin, a calcium-dependent cell-cell adhesion molecule responsible for the formation of epithelial adherent junctions, and activate the expression of mesenchymal markers [21]. Interestingly, in PCa epithelial cells, the EMT pattern can be induced by androgens through the activation of Snail, leading to a relevant modification in PCa cell migration and invasion, by possibly eluding TGF- $\beta$ functional involvement, and contributing to PCa metastatic behaviour [22]. Nevertheless, data regarding the androgens function in the control of EMT are conflicting. Although some reports have been demonstrated that androgens and AR play an active role in inducing EMT $[22,23]$, others have shown that EMT induction is due to androgen deprivation $[24,25]$ or low AR content [26] both in in vivo and in vitro prostate cancer settings. Moreover, androgen withdrawal promotes EMT in both normal and tumor prostate tissues, conferring a mesenchymal phenotype, despite differences in patient ages and tumor grades [27, 24]. Different in vitro and in vivo studies have suggested the effect of androgen deprivation on N-cadherin, E-cadherin, or vimentin expression, as well as a link between increased N-cadherin, androgen deprivation and metastasis formation in both human specimens and LNCaP xenografts $[28,29]$. Interestingly, in the LNCaP cell line the expression of both N-cadherin and ZEB1, a EMT direct regulator, is enhanced by androgen deprivation and is associated with chemotherapy resistance [24, 29]. ZEB1, a transcription factor whose expression has been reported greatly increased after chemical or physical castration in LuCaP35 normal prostate xenograft model, human prostate specimens and LNCaP cell line, by potentially functioning as AR transcriptional suppressor, intervenes in EMT induced by androgen deprivation through a bidirectional negative feedback loop with androgen receptor, revealing a potentially important consequence of a standard-of-care treatment for PCa [24]. On the contrary, ZEB2 expression seems to be positively regulated by androgens in LNCaP cells; moreover, in PC3 and DU145 cells the inverse relationship between these two factors results in a decrease of invasion and migration properties of AR overexpressing PC3/DU145 cell, induced by E-cadherin (a ZEB2 transcriptional target) expression increase [30], leading to the hypothesis that these events occur as a consequence of ZEB2 reduced levels/activity in these androgen independent cells. Interestingly, miRNAs are involved in the post-transcriptional modulation of ZEB2 expression mediated by AR [31]. miR200 is responsible for the control of EMT by targeting ZEB proteins. Higher levels of miR200a/miR200b were found in LNCaP cells. In addition, in these cells the silencing of AR determines a reduction of $\mathrm{miR} 200 \mathrm{a} / \mathrm{miR} 200 \mathrm{~b}$ levels prompting to the hypothesis that androgen receptor may positively regulates the expression of miR200 [32]. However, a ZEB-miR200s double-negative feedback loop, responsible for regulating EMT phenotype stability and interchangeability, exists [33,34].

In LNCaP cells androgen withdrawal, along with the activation of PI3K-AKT and ERK pathways, leads to neuroendocrine differentiation (NED), which is correlated with PCa progression to a hormone refractory state, and poor prognosis [35-38]. In prostatic carcinoma, during neuroendocrine differentiation prostate cancer cells shift to neuroendocrine-like cells, characterized for expressing typical neuroendocrine markers (e.g. chromogranin A and neuron specific enolase) [36]. These neuroendocrine cells secrete factors that exert mitogenic responses on adjacent cells and promote androgen independent growth of PCa cells [38]. In LNCaP cells Snail regulates NED induced by either androgen deprivation or Snail overexpression. Therefore, by inducing both NED and EMT in these androgen-dependent cells, Snail can provide a tight connection between these two main events [39].

AR maintenance is then necessary for EMT regulation since its loss favors EMT in androgenindependent PCa cells. In addition, in the context of prostate tumor microenvironment, a role for AR signaling in prostate fibroblasts in promoting prostate epithelial cell proliferation [40], as well as in mediating the epitheliumstroma functional interaction, and then favoring the EMT events leading to metastatic disease, has been proposed [41]. Thus, the control of AR expression as well as its coeffectors and downstream players may have significant effect on prostate cancer metastasis [42].

\section{EMT IN PROSTATE CANCER: ROLE OF ESTROGENS AND ESTROGEN-RELATED SIGNALING}

Interestingly, in the past years, a role for estrogen signaling in prostate cancer progression has been reported $[43,44]$. Estrogens can directly and indirectly affects the development and homeostasis of prostate gland; along with their receptors, they can play a pivotal role in prostate tumor initiation and progression. Prostatic estrogen receptor alpha (ER- $\alpha)$ and $-\beta(E R-\beta)$, whose expression patterns progressively differ during $\mathrm{PCa}$ progression, directly mediate the estrogens effect in this disease [45]. After binding with estrogen or estrogen-like compounds, ER- $\alpha$ and $-\beta$ can homo- or heterodimerize and in the nucleus activate different signaling pathways [46]. On the other hands, the estrogen receptors can also interfere with androgen synthesis by repressing the hypothalamicpituitary-gonadal (HPG) axis and, in turn, the direct effect on testis [47]. Then, due to the estrogen receptors presence in prostate, estrogens may directly function on prostate multiple sites. However, the role of ERs in the neoplastic events leading to $\mathrm{PCa}$ formation and progression still needs to be elucidated.

In normal prostate, ER- $\alpha$ and $-\beta$ and their relative variants have very different expression patterns [48-50]. 
ER- $\alpha$ is primarily expressed in prostatic stroma where it displays indirect effects on prostate epithelia [51]. Instead, ER- $\beta$ expression is found to be high in the gland epithelium, where ER- $\beta$ is responsible for regulating its proliferation and differentiation [51]. In prostate cancer, methylation of ER- $\alpha$ gene leads to its silencing, loss of ER- $\alpha$ transcription and ER- $\alpha$ protein [52, 53]. Interestingly, in several PCa cell lines as well as in hormone refractory tumors and metastasis, ER- $\alpha$ expression has been observed suggesting it re-appears as cancer progresses [51, 54]. However, prostate cancer stromal ER- $\alpha$ was reported to interact with cancer-associated fibroblasts (CAFs) to inhibit $\mathrm{PCa}$ invasion through the selective up-regulation of thrombospondin 2 and down-regulation of matrix metalloproteinase 3 suggesting a protective role of stromal ER- $\alpha$ in prostate cancer progression [55].

In adult prostate gland ER- $\beta$ represents the major estrogen receptor expressed; however, its role is not yet clearly established. ER- $\beta$ seemed to act as a suppressive player of proliferation process, stimulating the differentiation of adult prostate epithelial cells [56,57]. In hormone refractory prostate cancers and in high Gleason grade prostate carcinomas, ER- $\beta$ expression was found to be decreased, supporting the contention that loss of ER- $\beta$ correlates with disease progression and that could be considered as a prognostic factor of prostate cancer $[58,59]$. On the other hand, high ER- $\beta$ protein levels have reported to be correlated to a worse prognosis in patients affected by this disease [60]. Interestingly, ER- $\beta$, when activated by $5 \alpha$-androstane- $3 \beta-17 \beta-$ diol, maintains the epithelial characteristics and represses the acquirement of mesenchymal traits and invasive abilities in prostate cancer cells [61]. Under these conditions, in aggressive and poorly differentiated high Gleason grade PCas, ER- $\beta$ promotes the degradation of HIF- $1 \alpha$ (hypoxia inducible factor 1 alpha subunit), a crucial EMT player, and downregulates VEGF (vascular endothelial growth factor), the canonical HIF target. Loss of ER- $\beta$ therefore increases VEGF production, which employs neuropilin-1, a VEGF receptor, in driving EMT by promoting the nuclear localization of Snaill, through the inactivation of glycogen synthase kinase $3 \beta$ (GSK3 3 ), a critical regulator of Snail1 stability and localization [61]. In addition, due to deletion of PTEN that represents one of the most frequent prostate cancer genetic alteration, prostate tumorigenesis is promoted by BMI-1-mediated repression of ER- $\beta$ that enables the HIF-1 $\alpha /$ VEGF signaling altered in PCa cells [62]. Interestingly, ER- $\beta 2$ and ER- $\beta 5$ variants, which have tumor-promoting actions, are able to stabilize HIF- $1 \alpha$ and allow the expression of hypoxic genes in prostate cancer [63].

The capability of HIF to promote EMT might account for the common association of increased HIF levels and intratumoral hypoxia with a poor prognosis in different cancers, including prostate cancer. By suppressing ER- $\beta$ and stimulating HIF- $1 \alpha$-mediated
VEGF expression, hypoxia can promote the acquisition of mesenchymal features in PCa cells. Since ER- $\beta$ is sensitive to changes in tumor microenvironment, hypoxic conditions and TGF- $\beta 1$ signaling can reduce ER- $\beta$ levels and alter its action, favoring PCa progression.

Further studies, aimed to disclose all molecular mechanisms of estrogen signaling during this disease, are then needed to provide new insights into prostate cancer biology and novel hormonal therapeutic approaches for prostate cancer treatment.

\section{ROLE OF TGF- $\beta$ SIGNALING IN EMT INDUCTION OF PROSTATE CANCER CELLS}

Among the molecular factors involved in EMT induction, the TGF- $\beta$ (transforming growth factor $\beta$ ) represents one of the main player in inducing this process. In normal and premalignant cells, TGF- $\beta$ functions as an effective tumor suppressor, promoting apoptosis and cell differentiation [64]. Nevertheless, during tumor progression, its suppressive properties are lost, and, consequently, cells display a proliferative phenotype, initiate immune evasion, growth factors production and EMT [65]. In tumors, cancer cells bypass TGF- $\beta$ suppressive functions, either through directly inactivation of TGF- $\beta$ receptors or through repressing specific downstream elements, which maintain the epithelial phenotype [66].

Smad-dependent and Smad-independent pathways are responsible for TGF- $\beta$ induced EMT [66]. Upon activation by the binding of an active TGF- $\beta$ ligand, TGF- $\beta$ dimers cause the formation of heteromeric complex between specific TGF- $\beta$ type II and type I receptors, which, in their phosphorylated form, propagate the signal into the cell by phosphorylating Smad2 and Smad3 proteins (its receptor substrates). In the nucleus, the phosphorylated Smads bind to Smad4 and form a protein complex which, facilitating its association with DNAbinding cofactors, then activate sequential transcriptional programs in response to TGF- $\beta$ [66]. Smad-dependent pathway promotes TGF- $\beta$ tumor suppressive roles, whereas the activation of Smad-independent pathways, along with the loss of TGF- $\beta$ tumor suppressor roles, is responsible for its pro-oncogenic activity $[67,68]$. In prostate cancer, increased TGF- $\beta$ expression is correlated with progression to advanced disease, with a prognostic value for survival [69], while loss of T $\beta R I$ and T $\beta$ RII is associated with poor prognosis [70].

Also, TGF- $\beta$ family proteins communicate through non-canonical Smad-independent signaling, resulting in functionally different transcriptional outcomes. RasRaf-Erk mitogen-activated protein kinase (Erk/MAPK), Phosphotidylinositol-3kinase-Akt (PI3K/AKT) and JNK/ p38 MAP kinase (JNK/p38MAPK) signaling pathways are TGF- $\beta$ downstream effectors, each with distinct 
contributions to EMT [71]. TGF- $\beta$ stimulation of Erk through Ras, Raf, and downstream MAPK is necessary in EMT, as Erk signaling controls genes involved in ECMcell interactions and cellular motility [72]. Furthermore, the PI3K/AKT pathway represents an important player of TGF- $\beta$-mediated EMT; PI3K blockade leads to EMT inhibition, whereas forced expression can effectively disturb cellular junctions [72].

The phenotypic modification necessary for EMT likely occurs through non-Smad mediated TGF- $\beta$ signaling, while TGF- $\beta$ growth inhibitory functions are mediated by canonical Smad-dependent signaling [51]; however, a potential signaling synergy between non-Smad and Smad can occur, in turn inducing cellular plasticity and impacting EMT [73].

A role for TGF- $\beta$-induced EMT has been suggested in the development of benign prostatic hyperplasia $(\mathrm{BPH})$ where stromal cells are able to induce EMT, possibly through secreting TGF- $\beta 1$ and activating its signaling $[74,75]$. Stromal cells greatly influence the tumorigenesis in adjacent epithelia. Intraepithelial neoplasia in prostate cancer, combined with an increase in the amount of stromal cells, represents the direct consequence of the loss of TGF- $\beta$ responsiveness in fibroblasts. Thus, TGF- $\beta$ pathways in fibroblasts promotes prostate cancer by modulating the adjacent epithelial cell growth and its oncogenic ability [76, 77]. In addition, in prostate cancer, TGF- $\beta$ determines the nuclear accumulation of nuclear factor-kappa B (NF- $\kappa B)$, and for the morphological changes occurring towards a mesenchymal phenotype [78, 79]. However, EMT like features have been shown to be blocked by the inhibitor of NF- $\mathrm{KB}$ demonstrating that NF- $\mathrm{KB}$ is an important intermediary of TGF- $\beta$ mediated EMT in PCa [79]. Current information related to TGF- $\beta$ induced EMT in $\mathrm{PCa}$ are well documented albeit a conclusive evidence of EMT from human tissues and the role of TGF- $\beta$ (stromal and/or epithelial) in EMT induction in PCa is still missing.

TGF- $\beta$ is able to regulate AR gene targets in a close crosstalk with androgens, with AR-dependent outcomes $[80,41]$. The crosstalk between TGF- $\beta$ signaling and androgen axis may represent a crucial element for EMT expression. Changes in cytoskeleton reorganization induced by androgens may provide active movements that assist prostate cancer cells migration and metastasis. In castrate-resistant prostate tumors a dynamic $\mathrm{AR} / \beta$-catenin crosstalk leads to their increased nuclear co-localization and interaction [81]. The binding of $\beta$-catenin to cadherin represents a requirement for adhesion; however, its dissociation from the complex formed with cadherin enables it to reach the nucleus, where $\beta$-catenin functions as a transcription factor, and controls genes responsible for EMT in prostate cancer. Interestingly, in prostate cancer epithelium EMT can be induced through a different mechanism involving $\beta$-catenin activation by androgen signaling [22].
Conserved zinc finger transcription factors, controlled by upstream TGF- $\beta$ activities, have been reported to induce EMT functions [82,83]. Activated Snail, an EMT key transcription factor whose expression increases during $\mathrm{PCa}$ progression [84], represses E-cadherin expression, which is one of the hallmarks of EMT, in several cancer cell types [85-88]. Snail ectopic expression alone can cause EMT and improve cell motility in cancer cells [87, 89]. Moreover, its knockdown partially reverses EMT and enhances cell motility $[89,90]$.

In TGF- $\beta$-responsive LNCaP-T $\beta$ RII cells, Snail expression significantly increases after treatment with $5 \alpha$-dihydrotestosterone alone or in combination with TGF- $\beta$ indicating that androgens, by avoiding the effect evoked by TGF- $\beta$, can independently promote EMT [22]. In prostate cancer microenvironment Snail is able to interact not only with TGF- $\beta$ but also with epidermal growth factor (EGF) in downregulating the expression of HLA-I (human leukocyte antigen class I), which influences prostate cancer progression [91]. Moreover, in prostate cancer cells Snail knockdown significantly reverses HLA-I downregulation induced by TGF- $\beta$ and EGF, confirming that Snail is crucial for this process [91].

Genetically engineered mouse models provide direct evidence to support TGF- $\beta$ role in driving prostate tumor metastasis. TGF- $\beta$ signaling in vivo disruption was shown to accelerate the pathologic malignant prostatic phenotype of the TRAMP mouse model by altering prostate growth and inducing EMT [92].

The complex signaling pathways involving Smad and non-Smad proteins can play a pivotal role in orchestrating EMT and metastatic responses. The identification of new important players contributing to prostate tumor progression as well as additional TGF- $\beta$ signaling effectors, useful either prognostically or diagnostically for characterizing EMT, may allow the development of new therapeutical tools for this urological disease.

\section{EGF SIGNALING AND CROSSTALK IN PROSTATE CANCER}

EGF represents a crucial mitogenic factor able to control physiological prostatic functions [93]. However, following the binding to EGF receptor (EGFR), it stimulates cellular growth, vitality, migration and metastatic abilities of different tumors, including prostate cancer [94]. EGF and EGFR are aberrantly expressed in both androgen independent and metastatic $\mathrm{PCa}$, which possess heightened EMT related features, and are closely associated with aggressive phenotype, poor clinical prognosis, high Gleason score, reduced survival rate [95-97], then contributing to castrate resistant $\mathrm{PCa}$ and progression to metastasis. Interestingly, recent evidences have demonstrated an important role of EGF/ EGFR signaling in inducing epithelial-mesenchymal 
transition and thereby promoting cell motility in epithelial cells from several tumor types [98-101]. In carcinomas EMT marker expression and EGFR over-expression are almost simultaneous and this event is associated with enhanced metastasis [102]. In prostate cancer, the acquired mesenchymal spindle-like cell structure, the increased expression of fibronectin and N-cadherin, and the E-cadherin concurrent decrease, represent the specific traits of EMT induced by EGF [103]. In PC-3 cells EGF is able to induce EMT by promoting EMT itself and PC-3 cells motility through a protein kinase $\mathrm{C}(\mathrm{PKC}) / \mathrm{GSK}-$ $3 \beta /$ Snail signaling pathway. EGF promotes the stability of upregulated Snail by inducing PKC activation and consequently preventing GSK-3 $\beta$ phosphorylation activity, which in turn decreases Snail ubiquitination and increases its transcription [103]. The PI3K/AKT pathways has been reported to modulate the activity of GSK-3 $\beta$. Following its activation by $\mathrm{PI} 3 \mathrm{~K}$ phosphorylation, AKT phosphorylates GSK-3 $\beta$ and inhibits its activity [104]. EGF induced EMT was found to be mainly dependent on Akt activation, as inhibition of Akt signaling abolished EGF driven EMT in PCa cell lines $[105,106]$. However, although EGFR overexpression and EGF signaling constitutive activation in prostate cancer are associated with poor prognosis, the exact role played by EGF/EGFR in the progression and development of this disease still needs to be elucidated. Recent data underscore the importance of the heat shock protein 27 (Hsp27) in EGF-mediated EMT in prostate cancer suggesting that EGF-induced EMT requires Hsp27 and involves $\beta$-catenin/Slug signaling pathway [107]. Hsp27 is a molecular chaperone, whose expression is upregulated following different cellular stresses, which plays a pivotal role in controlling cellular migration and invasion [108]. Highly expressed in prostate cancer [109], Hsp27 is correlated with aggressive cancer behaviour and metastatic potential [110], and represents a prognostic marker of poor clinical outcome [111]. Its increased expression correlates with prostate cancer progression to castration-resistant disease [112] and it is essential for EGF-promoted cell migration and invasion, as well as for EMT markers expression [108], AKT and GSK3 $\beta$ phosphorylation induced by EGF, and consequently for $\beta$-catenin stabilization [107]. These latter events, in turn, allow $\beta$-catenin nuclear translocation, EMT transcription factor Slug consequent activation and, finally, prostate cancer migration and invasion [107]. Hsp27 may act as an inducer of EMT activated by EGF; in addition, in prostate cancer it plays a crucial role in controlling both E-cadherin expression modulation mediated by $\beta$-catenin and EMT transcriptional regulation. Interestingly, in high grade PCa Hsp27 expression correlates with an increase in the expression of EMT player Twist [113]. A strong correlation between both Hsp27 and EGF and advanced prostate cancer, as well as with EMT through IL-6/STAT3/ Twist pathway, has been reported $[113,114]$. Furthermore, EGF favors PCa progression through a ROS/STAT3/HIF-
$1 \alpha /$ Twist $1 / \mathrm{N}$-cadherin signaling pathway [114]. Twist1 is a highly conserved, basic helix-loop-helix (bHLH) domaincontaining transcription factor able to induce metastasis [115], and also EMT. In prostate cancer a key role for Twist1 during EGF-induced EMT and tumor invasion has been proposed since it acts as a crucial downstream mediator of these events. In prostate cancer EGF stimulates tumor progression via the coordinated ROS production, the phosphorylation of STAT3 (required for EGF-induced upregulation of HIF-1 $\alpha$ ) and the consequent induction of HIF-1 $\alpha /$ Twist1/N-cadherin signaling pathway [114].

Interestingly, EGF can interact with Src tyrosine kinase pathway in the induction of EMT in TMPRSS2ERG positive prostate cancers [116]. TMPRSS2-ERG is a fusion transcript that emerges as prostate cancer cells specific biomarker; when overexpressed, it plays a pivotal role in prostate cancer transformation, EMT and invasion [117-120]. ERG (ETS-related-gene), which represents the most commonly over-expressed and translocated oncogene in PCa cells [121], arises from genomic fusion between androgen-regulated TMPRSS2 gene promoter upstream sequences and ERG coding sequences [122, 120]. Despite androgen represents the major driver of TMPRSS2-ERG overexpression in primary tumors, EGF and Src can modulate the expression of TMPRSS2ERG in PCa cells through a different pathway where they upregulate ERG expression via miR-30 modulation [116]. This novel crosstalk between the androgen/AR and EGF/Src signaling pathways, by connecting EGF and Src signaling pathways to ERG induction and EMT, via miR-30b silencing, assumes a relevant role in castrationresistant $\mathrm{PCa}$, where the androgen receptor is abnormally activated despite androgen absence.

\section{EMT AND CANCER STEM / PROGENITORS CELLS IN PROSTATE CANCER}

Recently, EMT has been linked to stem cell phenotype [123] since EMT acquires stem cell-like features, such as self-renewal and slow proliferation [124,125]. After androgen-deprivation therapy, both cancer cells with EMT markers and those with cancer stem cells (CSCs) markers increase in human prostate cancer specimens [126,127]. Stem-like stem/progenitors cells acquire more complete EMT molecular characteristics and exhibit more aggressive abilities. Specifically, prostate CSCs display increased EMT markers as well as increased tumorigenesis, migration and invasion ability [128]. The molecular mechanism underlying EMT and regulation of stemness is still not clear. Cell signaling pathways including PI3K/AKT, EGF/EGFR, STAT3/5, Wnt/ $\beta$ catenin, have been shown to sustain stem cell growth and self-renewal further confirming the important function played by stem cell/progenitors cells in PCa progression 
[129, 130]. EMT activator Twist1 can promote both stemness and EMT properties [131, 132], providing a connection between CSCs and EMT. Moreover, in PCa the $\mathrm{PI} 3 \mathrm{~K} / \mathrm{AKT} / \mathrm{mTOR}$ signaling activation induces EMT and enhances CSCs phenotype, responsible for the associated radioresistance of this disease [133]. Interestingly, AR, whose expression is low in prostate cancer stem cell/ progenitors cells, plays a negative role in EMT of these cells, by controlling AKT pathway [134].

$\mathrm{PCa}$ cancer stem/progenitor cells and metastasis are inhibited by miR-34a through the direct repression of CD44, a major adhesion molecule of the extracellular matrix, which is also a marker of CSCs [135]. CD44 plays an important role in inducing EMT and/or in maintaining the mesenchymal phenotype in PCa [136,137]. As a marker of cancer stem/progenitor cells, CD44, by promoting EMT and metastasis in PCa carcinogenesis, may serve a new potential prostate cancer therapeutic approach. Furthermore, CD44 high expression level was associated with biochemical recurrence and distant metastasis, making CD44 a marker of poor prognosis in prostate cancer [136]. In addition, CD44+ stem-like cell population increases in prostate cancer cells following ADT-induced TGF- $\beta$ signaling activation leading to dedifferentiated phenotype of prostate cancer cells [137]. $\mathrm{CD} 44^{+}$cancer stem/progenitor cells, in response to TGF- $\beta$ signaling, not only can initiate the EMT but also can regulate the mesenchymal phenotype in prostate cancer cells.

However, additional signaling pathways are responsible for regulation of stemness and EMT of $\mathrm{PCa}$ cells. Overexpressed N-cadherin, a marker of ongoing EMT, achieves EMT, stemness promoting function and metastatic ability by activating the ErbB signaling in $\mathrm{PCa}$ cells, further supporting the hypothesis that N-cadherin could be a promising target in PCa therapy [138]. Abnormal expression of $\mathrm{N}$-cadherin has been shown as crucial not only to metastasis, but also to castration resistance [28, 29], and associated with poor prognosis $[138,139]$. Simultaneous upregulation of N-cadherin and downregulation of E-cadherin have been found in more aggressive cultured PCa cell lines and in primary and metastatic prostate tumors [140-142]. Mice xenograft models treated with $\mathrm{N}$-cadherin monoclonal antibody have

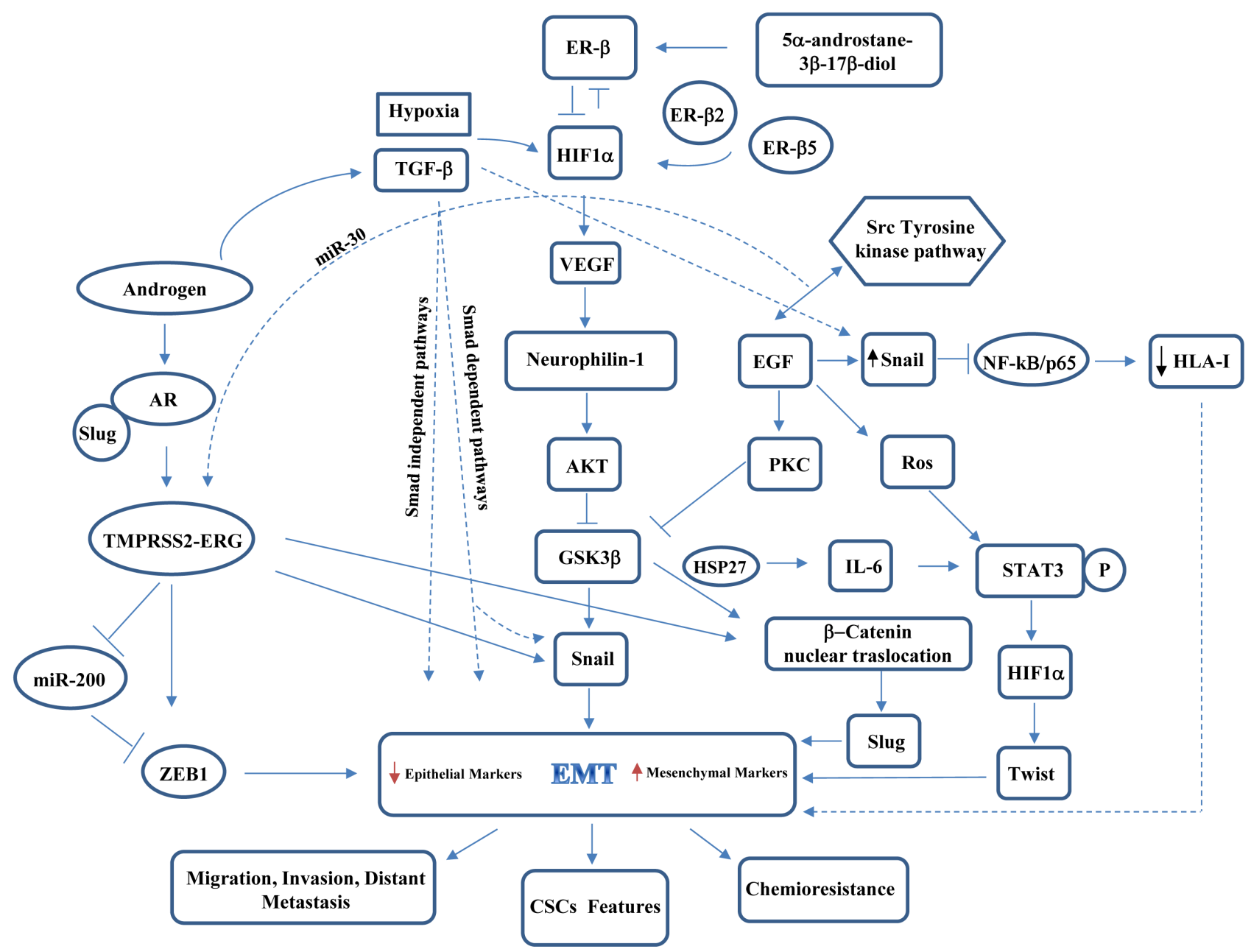

Figure 1: Schematic representation of main players and crosstalks governing EMT in prostate cancer. 
displayed an inhibition of tumor growth and metastasis [28]. Recent study showed that miR-145 played a pivotal role in inhibiting migration, invasion, stemness, and EMT properties of prostate cancer cells via different targets $[143,144]$. In gastric cancer $\mathrm{N}$-cadherin is miR-145 direct target and promotes the invasion and metastasis cascade [145]. However, since N-cadherin promotes prostate cancer cells stemness features and EMT, a role for $\mathrm{N}$-cadherin in mediating miR-145 function in the regulation of these events has been proposed [146].

It is well established that Wnt pathway has a developmental role in tissues and organisms. However, the aberrant activation of the $\mathrm{Wnt} / \beta$-catenin pathway correlates with EMT features and also positively affects proliferation and invasiveness in PCa [147]. Interestingly, miR-320, a CD44+ prostate CSCs negative regulator, can inhibit the expression of $\beta$-catenin and repress CSCs via $W n t / \beta$-catenin pathway inhibition [148]. In addition, some CSCs features (e.g. tumor-spheres formation, tumorigenicity, chemioresistance) are enhanced by downregulation of miR-320 [148].

In NOD/SCID IL2RY null mice Erismodegib (an inhibitor of Sonic hedgehog pathway) can inhibit the growth of human prostate CSCs and EMT by upregulating miR-200 and consequently inhibiting Snail, Slug and Zeb1 transcription factors, and preventing Bmi-1, which contributes to the self-renewal capacity of prostate CSCs, through miR-128 induction, respectively [149].

Then, many miRNAs, by regulating EMT, cancer cell migration and invasion, and CSCs properties may represent the common step combining EMT, CSCs, and drug resistance.

\section{CONCLUSIONS}

The reappearance of the tumor acquired drug resistance along with some features of EMT and stemness have been responsible for the failure of traditional chemotherapy and/or androgen ablation treatment for the therapy of advanced/metastatic PCa. Thus, to prevent the metastatic spread, novel strategies are being used, which inhibit cancer cell proliferation, EMT and stem cell-like properties.

Altered miRNAs are correlated to prostate cancer initiation, progression and metastasis [150], and their aberrant expression can allow the progression to resistant prostate tumors [151]. In androgen independent prostate cancers miR-221/-222 and miR-125b are frequently upregulated promoting prostate cancers cells resistance to androgen withdrawal and androgen-independent cell growth [152, 153]. Furthermore, circulating miRNAs are correlated with $\mathrm{PCa}$ development and its progression to androgen-independent disease. Elevated expression of miR-141, miR-375 and miR-378 have been found in the serum of prostate cancers patients suggesting their potential use as PCa diagnostic biomarkers [154].
On the other hands, different miRNAs, capable of inhibiting cancer progression, are down-expressed in androgen independent prostate tumors, resulting in high and low levels of mesenchymal and epithelial markers, respectively, that can induce EMT, increase prostate cancer aggressiveness and resistance to androgen deprivation therapy [155].

Due to their advantageous in vivo stabilities and pharmacokinetics characteristics, small molecule drugs have emerged as favorable tool in the regulation of miRNAs and in potentially suppressing drug resistance in PCa [156, 157]. Since the modification of abnormal miRNAs levels can make resistant $\mathrm{PCa}$ cells more sensitive to small molecule drugs, the combined use of these innovative agents (such as small molecules and miRNAs) may represent a favorable approach for the therapeutic treatment of resistant prostate cancers.

Current studies regarding prostate tumor microenvironment have highlight that signals arising from microenvironment can play a key role in governing EMT and highly influence cancer progression or clinical outcomes in PCa patients. Several key regulators and inducers, supported by their crosstalking signaling pathways and ligands, are then responsible for the transition to a dedifferentiated invasive phenotype (Figure 1). The detailed characterization of the crosstalks between EMT and castration resistance may offer the potential to identify novel prognostic or diagnostic markers as well as to develop new tailored therapeutic approaches for PCa management.

\section{GRANT SUPPORT}

This work was supported by grant "Progetto ONCONET $^{2.0}$ - Linea progettuale 14 per l'implementazione della prevenzione e diagnosi precoce del tumore alla prostata e testicolo - Regione Campania, Italy" (to G.F), Ministero dell'Universita`e Ricerca, PRIN Grant 2015B7M39T (to B.M.V).

\section{CONFLICTS OF INTEREST}

The authors declare no conflict of interest.

\section{REFERENCES}

1. Siegel RL, Miller KD, Jemal A. Cancer statistics, 2015. CA Cancer J Clin. 2015; 65:5-29.

2. Boudadi K, Antonarakis ES. Resistance to Novel Antiandrogen Therapies in Metastatic Castration-Resistant Prostate Cancer. Clin Med Insights Oncol. 2016; 10:1-9.

3. Bitting RL, Schaeffer D, Somarelli JA, Garcia-Blanco MA, Armstrong AJ. The role of epithelial plasticity in prostate cancer dissemination and treatment resistance. Cancer Metastasis Rev. 2014; 33:441-468. 
4. Marín-Aguilera M, Codony-Servat J, Reig Ò, Lozano JJ, Fernández PL, Pereira MV, Jiménez N, Donovan M, Puig P, Mengual L, Bermudo R, Font A, Gallardo E, et al. Epithelial-to-mesenchymal transition mediates docetaxel resistance and high risk of relapse in prostate cancer. Mol Cancer Ther. 2014; 13:1270-1284.

5. Thiery JP. Epithelial-mesenchymal transitions in development and pathologies. Curr Opin Cell Biol. 2003; 15:740-746.

6. Khan MI, Hamid A, Adhami VM, Lall RK, Mukhtar H. Role of Epithelial Mesenchymal Transition in Prostate Tumorigenesis. Curr Pharm Des. 2015; 21:1240-1248.

7. Ye X, Weinberg RA. Epithelial-Mesenchymal Plasticity: A Central Regulator of Cancer Progression. Trends Cell Biol. 2015; 25:675-686.

8. Smith BN, Bhowmick NA. Role of EMT in Metastasis and Therapy Resistance. J Clin Med. 2016; 5:17.

9. Kalluri R, Weinberg RA. The basics of epithelialmesenchymal transition. J Clin Invest. 2009; 119:14201428.

10. Thiery JP. Epithelial-mesenchymal transitions in tumour progression. Nat Rev Cancer. 2002; 2:442-454.

11. Nieto MA. The ins and outs of the epithelial to mesenchymal transition in health and disease. Annu Rev Cell Dev Biol. 2011; 27:347-376.

12. Wang Y, Liu J, Ying X, Lin PC, Zhou BP. Twist-mediated Epithelial-mesenchymal Transition Promotes Breast Tumor Cell Invasion via Inhibition of Hippo Pathway. Sci Rep. 2016; 6:24606.

13. Little AC, Sham D, Hristova M, Danyal K, Heppner DE, Bauer RA, Sipsey LM, Habibovic A, van der Vliet A. DUOX1 silencing in lung cancer promotes EMT, cancer stem cell characteristics and invasive properties. Oncogenesis. 2016; 5:e261.

14. Polireddy K, Chen Q. Cancer of the Pancreas: Molecular Pathways and Current Advancement in Treatment. J Cancer. 2016; 7:1497-1514.

15. Van der Horst G, Bos L, van der Pluijm G. Epithelial plasticity, cancer stem cells, and the tumor-supportive stroma in bladder carcinoma. Mol Cancer Res. 2012; 10:995-1009.

16. Tsai JH, Yang J. Epithelial-mesenchymal plasticity in carcinoma metastasis. Genes Dev. 2013; 27:2192-2206.

17. Grant CM, Kyprianou N. Epithelial mesenchymal transition (EMT) in prostate growth and tumor progression. Translat Androl Urol. 2013; 2:202-211.

18. Wang L, Song G, Tan W, Qi M, Zhang L, Chan J, Yu J, Han J, Han B. miR-573 inhibits prostate cancer metastasis by regulating epithelial-mesenchymal transition. Oncotarget. 2015; 6:35978-35990. doi: 10.18632/oncotarget.5427.

19. Heinlein CA, Chang C. Androgen receptor in prostate cancer. Endocr Rev. 2004; 25:276-308.

20. Tan ME, Li J, Xu HE, Melcher K, Yong E. Androgen receptor: structure, role in prostate cancer and drug discovery. Acta Pharmacol Sin. 2015; 36:3-23.

21. Nieto M, Finn S, Loda M, Hahn WC. Prostate cancer: Refocusing on androgen receptor signaling. Int J Biochem Cell Biol. 2007; 39:1562-1568.

22. Zhu ML, Kyprianou N. Role of androgens and the androgen receptor in epithelial-mesenchymal transition and invasion of prostate cancer cells. FASEB J. 2010; 24:769-777.

23. Anose BM, Sanders MM. Androgen Receptor Regulates Transcription of the ZEB1 Transcription Factor. Int J Endocrinol. 2011; 2011:903918.

24. Sun Y, Wang BE, Leong KG, Yue P, Li L, Jhunjhunwala S, Chen D, Seo K, Modrusan Z, Gao WQ, Settleman J, Johnson L. Androgen Deprivation Causes EpithelialMesenchymal Transition in the Prostate: Implications for Androgen-Deprivation Therapy. Cancer Res. 2012; 72:527536.

25. Byrne NM, Nesbitt H, Ming L, McKeown SR, Worthington $\mathrm{J}$, McKenna DJ. Androgen deprivation in $\mathrm{LNCaP}$ prostate tumour xenografts induces vascular changes and hypoxic stress, resulting in promotion of epithelial-to-mesenchymal transition. Br J Cancer. 2016; 114:659-668.

26. Izumi K, Fang LY, Mizokami A, Namiki M, Li L, Lin WJ, Chang C. Targeting the androgen receptor with siRNA promotes prostate cancer metastasis through enhanced macrophage recruitment via CCL2/CCR2-induced STAT3 activation. EMBO Mol Med. 2013; 5:1383-1401.

27. Best CJ, Gillespie JW, Yi Y, Chandramouli GV, Perlmutter MA, Gathright Y, Erickson HS, Georgevich L, Tangrea MA, Duray PH, González S, Velasco A, Linehan WM, et al. Molecular Alterations in Primary Prostate Cancer After Androgen Ablation Therapy. Clin Cancer Res. 2005; 11 : 6823-6834.

28. Tanaka H, Kono E, Tran CP, Miyazaki H, Yamashiro J, Shimomura T, Fazli L, Wada R, Huang J, Vessella RL, An J, Horvath S, Gleave M, et al. Monoclonal antibody targeting of N-cadherin inhibits prostate cancer growth, metastasis and castration resistance. Nat Med. 2010; 16:1414-1420.

29. Jennbacken K, Tesan T, Wang W, Gustavsson H, Damber JE, Welén K. N-cadherin increases after androgen deprivation and is associated with metastasis in prostate cancer. Endocr Relat Cancer. 2010; 17:469-479.

30. Jacob S, Nayak S, Fernandes G, Barai RS, Menon S, Chaudhari UK, Kholkute SD, Sachdeva G. Androgen receptor as a regulator of ZEB2 expression and its implications in epithelial-to-mesenchymal transition in prostate cancer. Endocr Relat Cancer. 2014; 21:473-486.

31. Gregory PA, Bracken CP, Smith E, Bert AG, Wright JA, Roslan S, Morris M, Wyatt L, Farshid G, Lim YY, Lindeman GJ, Shannon MF, Drew PA, et al. An autocrine TGF- $\beta / Z$ ZB $/$ miR-200 signaling network regulates establishment and maintenance of epithelial-mesenchymal transition. Mol Biol Cell. 2011; 22:1686-1698.

32. Gregory PA, Bert AG, Paterson EL, Barry SC, Tsykin 
A, Farshid G, Vadas MA, Khew-Goodall Y, Goodall GJ. The miR-200 family and miR-205 regulate epithelial to mesenchymal transition by targeting ZEB1 and SIP1. Nat Cell Biol. 2008; 10:593-601.

33. Bracken CP, Gregory PA, Kolesnikoff N, Bert AG, Wang J, Shannon MF, Goodall GJ. A double-negative feedback loop between ZEB1-SIP1 and the microRNA-200 family regulates epithelial-mesenchymal transition. Cancer Res. 2008; 68:7846-7854.

34. Brabletz S, Brabletz T. The ZEB/miR-200 feedback loop - a motor of cellular plasticity in development and cancer? EMBO Rep 2010; 11:670-677.

35. Wu C, Huang J. Phosphatidylinositol 3-kinase-AKTmammalian target of rapamycin pathway is essential for neuroendocrine differentiation of prostate cancer. J Biol Chem. 2007; 282:3571-3583.

36. Parimi V, Goyal R, Poropatich K, Yang XJ. Neuroendocrine differentiation of prostate cancer: a review. Am J Clin Exp Urol. 2014; 2:273-285.

37. Hu CD, Choo R, Huang J. Neuroendocrine Differentiation in Prostate Cancer: A Mechanism of Radioresistance and Treatment Failure. Front Oncol. 2015; 5:90.

38. Komiya A, Suzuki H, Imamoto T, Kamiya N, Nihei N, Naya Y, Ichikawa T, Fuse H. Neuroendocrine differentiation in the progression of prostate cancer. Int J Urol. 2009; 16:3744.

39. McKeithen D, Graham T, Chung LWK, Odero-Marah V. Snail Transcription Factor Regulates Neuroendocrine Differentiation in LNCaP Prostate Cancer Cells. Prostate. 2010; 70:982-992.

40. Niu Y, Altuwaijri S, Yeh S, Lai KP, Yu S, Chuang KH, Huang SP, Lardy H, Chang C. Targeting the stromal androgen receptor in primary prostate tumors at earlier stages. Proc Natl Acad Sci U S A. 2008; 105:12188-12193.

41. Zhu ML, Kyprianou N. Androgen receptor and growth factor signaling cross-talk in prostate cancer cells. Endocr Relat Cancer. 2008; 15:841-849.

42. D'Aniello C, Cavaliere C, Cecere SC, Di Napoli M, Gargiulo P, Della Pepa C, Pisconti S. GNRH analogues and its role in CRPC. WCRJ. 2014; 1:e358.

43. Prins GS, Huang L, Birch L, Pu Y. The Role of Estrogens in Normal and Abnormal Development of the Prostate Gland. Ann N Y Acad Sci. 2006; 1089:1-13.

44. Bonkhoff H, Berges R. The evolving role of oestrogens and their receptors in the development and progression of prostate cancer. Eur Urol. 2009; 55:533-542.

45. Lau KM, To KF. Importance of Estrogenic Signaling and Its Mediated Receptors in Prostate Cancer. Int J Mol Sci. 2016; $17: 1434$.

46. Heldring N, Pike A, Andersson S, Matthews J, Cheng G, Hartman J, Tujague M, Ström A, Treuter E, Warner M, Gustafsson JA. Estrogen receptors: how do they signal and what are their targets. Physiol Rev. 2007; 87:905-931.

47. Härkönen PL, Mäkelä SI. Role of estrogens in development of prostate cancer. J Steroid Biochem Mol Biol. 2004; 92:297-305.

48. Ye Q, Chung LW, Cinar B, Li S, Zhau HE. Identification and characterization of estrogen receptor variants in prostate cancer cell lines. J Steroid Biochem Mol Biol. 2000; 75:2131.

49. Leung YK, Mak P, Hassan S, Ho SM. Estrogen receptor (ER)- $\beta$ isoforms: A key to understanding ER- $\beta$ signaling. Proc Natl Acad Sci USA. 2006; 103:13162-13167.

50. Lee MT, Ouyang B, Ho SM, Leung YK. Differential expression of estrogen receptor beta isoforms in prostate cancer through interplay between transcriptional and translational regulation. Mol Cell Endocrinol. 2013; 376:125-135.

51. Leav I, Lau KM, Adams JY, McNeal JE, Taplin ME, Wang J, Singh H, Ho SM. Comparative Studies of the Estrogen Receptors $\beta$ and $\alpha$ and the Androgen Receptor in Normal Human Prostate Glands, Dysplasia, and in Primary and Metastatic Carcinoma. Am J Pathol. 2001; 159:79-92.

52. Lau KM, LaSpina M, Long J, Ho SM. Expression of estrogen receptor (ER)-alpha and ER-beta in normal and malignant prostatic epithelial cells: regulation by methylation and involvement in growth regulation. Cancer Res. 2000; 60:3175-3182.

53. Li LC, Chui R, Nakajima K, Oh BR, Au HC, Dahiya R. Frequent methylation of estrogen receptor in prostate cancer: correlation with tumor progression. Cancer Res. 2000; 60:702-706.

54. Bonkhoff H, Fixemer T, Hunsicker I, Remberger K. Estrogen Receptor Expression in Prostate Cancer and Premalignant Prostatic Lesions. Am J Pathol. 1999; 155:641-647.

55. Slavin S, Yeh CR, Da J, Yu S, Miyamoto H, Messing EM, Guancial E, Yeh S. Estrogen receptor $\alpha$ in cancerassociated fibroblasts suppresses prostate cancer invasion via modulation of thrombospondin 2 and matrix metalloproteinase 3. Carcinogenesis. 2014; 35:1301-1309.

56. Yu S, Wong YC, Wang XH, Ling MT, Ng CF, Chen $\mathrm{S}$, Chan FL. Orphan nuclear receptor estrogen-related receptor-beta suppresses in vitro and in vivo growth of prostate cancer cells via $\mathrm{p} 21$ (WAF1/CIP1) induction and as a potential therapeutic target in prostate cancer. Oncogene. 2008; 27:3313-3328.

57. Imamov O, Morani A, Shim GJ, Omoto Y, ThulinAndersson C, Warner M, Gustafsson JA. Estrogen receptor $\beta$ regulates epithelial cellular differentiation in the mouse ventral prostate. Proc Natl Acad Sci U S A. 2004; 101:93759380.

58. Latil A, Bièche I, Vidaud D, Lidereau R, Berthon P, Cussenot O, Vidaud M. Evaluation of androgen, estrogen (ER alpha and ER beta), and progesterone receptor expression in human prostate cancer by real-time quantitative reverse transcription-polymerase chain reaction assays. Cancer Res. 2001; 61:1919-1926. 
59. Slusarz A, Jackson GA, Day JK, Shenouda NS, Bogener JL, Browning JD, Fritsche KL, MacDonald RS, BeschWilliford CL, Lubahn DB. Aggressive Prostate Cancer Is Prevented in ER $\alpha \mathrm{KO}$ Mice and Stimulated in ER $\beta K O$ TRAMP Mice. Endocrinology. 2012; 153:4160-4170.

60. Nanni S, Benvenuti V, Grasselli A, Priolo C, Aiello A, Mattiussi S, Colussi C, Lirangi V, Illi B, D'Eletto M, Cianciulli AM, Gallucci M, De Carli P, et al. Endothelial NOS, estrogen receptor $\beta$, and HIFs cooperate in the activation of a prognostic transcriptional pattern in aggressive human prostate cancer. J Clin Invest. 2009; 119:1093-1108.

61. Mak P, Leav I, Pursell B, Bae D, Yang X, Taglienti CA, Gouvin LM, Sharma VM, Mercurio AM. ER $\beta$ Impedes Prostate Cancer EMT by Destabilizing HIF-1 $\alpha$ and Inhibiting VEGF-Mediated Snail Nuclear Localization: Implications for Gleason Grading. Cancer Cell. 2010; 17:319-332.

62. Mak P, Li J, Samanta S, Mercurio AM. ER $\beta$ regulation of NF- $\kappa \mathrm{B}$ activation in prostate cancer is mediated by HIF-1. Oncotarget. 2015; 6:40247-40254. doi: 10.18632/ oncotarget.5377.

63. Dey P, Velazquez-Villegas LA, Faria M, Turner A, Jonsson P, Webb P, Williams C, Gustafsson JÅ, Ström AM. Estrogen Receptor $\beta 2$ Induces Hypoxia Signature of Gene Expression by Stabilizing HIF-1 $\alpha$ in Prostate Cancer. PLoS One. 2015; 10:e128239.

64. Derynck R, Akhurst RJ. Differentiation plasticity regulated by TGF- $\beta$ family proteins in development and disease. Nat Cell Biol. 2007; 9:1000-1004.

65. Bierie B, Moses HL. TGF-beta and cancer. Cytokine Growth Factor Rev. 2006; 17:29-40.

66. Massagué J. TGF $\beta$ in Cancer. Cell. 2008; 134:215-230.

67. Nagaraj NS, Datta PK. Targeting the Transforming Growth Factor- $\beta$ Signaling Pathway in Human Cancer. Expert Opin Investig Drugs. 2010; 19:77-91.

68. Chaudhury A, Howe PH. The Tale of Transforming Growth Factor- $\beta$ (TGF $\beta$ ) Signaling: A Soigné Enigma. IUBMB Life. 2009; 61:929-939.

69. Wikström P, Stattin P, Franck-Lissbrant I, Damber JE, Bergh A. Transforming growth factor betal is associated with angiogenesis, metastasis, and poor clinical outcome in prostate cancer. Prostate. 1998; 37:19-29.

70. Kim IY, Ahn HJ, Lang S, Oefelein MG, Oyasu R, Kozlowski JM, Lee C. Loss of expression of transforming growth factor-beta receptors is associated with poor prognosis in prostate cancer patients. Clin Cancer Res. 1998; 4:1625-1630.

71. Zhang YE. Non-Smad pathways in TGF- $\beta$ signaling. Cell Res. 2009; 19:128-139.

72. Gonzalez DM, Medici D. Signaling mechanisms of the epithelial-mesenchymal transition. Sci Signal. 2014; 7:re8.

73. Derynck R, Muthusamy BP, Saeteurn KY. Signaling pathway cooperation in TGF- $\beta$-induced epithelial- mesenchymal transition. Curr Opin Cell Biol. 2014; 31:5666.

74. Hu S, Yu W, Lv TJ, Chang CS, Li X, Jin J. Evidence of TGF- $\beta 1$ mediated epithelial-mesenchymal transition in immortalized benign prostatic hyperplasia cells. Mol Membr Biol. 2014; 31:103-110.

75. Slabáková E, Pernicová Z, Slavíčková E, Staršíchová A, Kozubík A, Souček K. TGF- $\beta 1$-induced EMT of nontransformed prostate hyperplasia cells is characterized by early induction of SNAI2/Slug. Prostate. 2011; 71:13321343.

76. Bhowmick NA, Chytil A, Plieth D, Gorska AE, Dumont N, Shappell S, Washington MK, Neilson EG, Moses HL. TGF-beta signaling in fibroblasts modulates the oncogenic potential of adjacent epithelia. Science. 2004; 303:848-851.

77. Shiao SL, Chu GCY, Chung LWK. Regulation of prostate cancer progression by the tumor microenvironment. Cancer Lett. 2016; 380:340-348.

78. Nguyen DP, Li J, Yadav SS, Tewari AK. Recent insights into NF-kB signalling pathways and the link between inflammation and prostate cancer. BJU Int. 2013; 114:168 176.

79. Zhang Q, Helfand BT, Jang TL, Zhu LJ, Chen L, Yang XJ, Kozlowski J, Smith N, Kundu SD, Yang G, Raji AA, Javonovic B, Pins M, et al. Nuclear Factor- $\kappa$ B-Mediated Transforming Growth Factor- $\beta$-Induced Expression of Vimentin Is an Independent Predictor of Biochemical Recurrence after Radical Prostatectomy. Clin Cancer Res. 2009; 15:3557-3567.

80. Zhu ML, Partin JV, Bruckheimer EM, Strup SE, Kyprianou N. TGF-beta signaling and androgen receptor status determine apoptotic cross-talk in human prostate cancer cells. Prostate. 2008; 68:287-295.

81. Wang G, Wang J, Sadar MD. Crosstalk between the Androgen Receptor and $\beta$-Catenin in Castrate Resistant Prostate Cancer. Cancer Res. 2008; 68:9918-9927.

82. Peinado H, Olmeda D, Cano A. Snail, Zeb and bHLH factors in tumour progression: an alliance against the epithelial phenotype? Nat Rev Cancer. 2007; 7:415-428.

83. Lamouille S, Xu J, Derynck R. Molecular mechanisms of epithelial-mesenchymal transition. Nat Rev Mol Cell Biol. 2014; 15:178-196.

84. Smith BN, Odero-Marah VA. The role of Snail in prostate cancer. Cell Adh Migr. 2012; 6:433-441.

85. Thuault S, Tan EJ, Peinado H, Cano A, Heldin $\mathrm{CH}$, Moustakas A. HMGA2 and Smads Co-regulate SNAIL1 Expression during Induction of Epithelial-to-Mesenchymal Transition. J Biol Chem. 2008; 283:33437-33446.

86. Dong C, Wu Y, Yao J, Wang Y, Yu Y, Rychahou PG, Evers BM, Zhou BP. G9a interacts with Snail and is critical for Snail-mediated E-cadherin repression in human breast cancer. J Clin Invest. 2012; 122:1469-1486.

87. Argast GM, Krueger JS, Thomson S, Sujka-Kwok I, Carey K, Silva S, O'Connor M, Mercado P, Mulford IJ, Young 
GD, Sennello R, Wild R, Pachter JA, et al. Inducible expression of TGF $\beta$, snail and Zeb1 recapitulates EMT in vitro and in vivo in a NSCLC model. Clin Exp Metastasis. 2011; 28:593-614.

88. Pon YL, Zhou HY, Cheung AN, Ngan HY, Wong AS. p70 S6 kinase promotes epithelial to mesenchymal transition through snail induction in ovarian cancer cells. Cancer Res. 2008; 68:6524-6532.

89. Wang H, Wang HS, Zhou BH, Li CL, Zhang F, Wang XF, Zhang G, Bu XZ, Cai SH, Du J. Epithelial-mesenchymal transition (EMT) induced by TNF- $\alpha$ requires AKT/GSK$3 \beta$-mediated stabilization of snail in colorectal cancer. PLoS One. 2013; 8:e56664.

90. Wu Y, Deng J, Rychahou PG, Qiu S, Evers BM, Zhou BP. Stabilization of Snail by NF- $\kappa B$ is Required for Inflammation-Induced Cell Migration and Invasion. Cancer Cell. 2009; 15:416-428.

91. Chen XH, Liu ZC, Zhang G, Wei W, Wang XX, Wang $\mathrm{H}$, Ke HP, Zhang F, Wang HS, Cai SH, Du J. TGF- $\beta$ and EGF induced HLA-I downregulation is associated with epithelial-mesenchymal transition (EMT) through upregulation of snail in prostate cancer cells. Mol Immunol. $2015 ; 65: 34-42$

92. Pu H, Collazo J, Jones E, Gayheart D, Sakamoto S, Vogt A, Mitchell B, Kyprianou N. Dysfunctional transforming growth factor-beta receptor II accelerates prostate tumorigenesis in the TRAMP mouse model. Cancer Res. 2009; 69:7366-7374.

93. De Miguel P, Royuela, Bethencourt R, Ruiz A, Fraile B, Paniagua R. Immunohistochemical comparative analysis of transforming growth factor alpha, epidermal growth factor, and epidermal growth factor receptor in normal, hyperplastic and neoplastic human prostates. Cytokine. 1999; 11:722-777.

94. Lu X, Kang Y. Epidermal growth factor signalling and bone metastasis. Br J Cancer. 2010; 102:457-461.

95. Salomon DS, Brandt R, Ciardiello F, Normanno N. Epidermal growth factor-related peptides and their receptors in human malignancies. Crit Rev Oncol Hematol. 1995; 19:183-232.

96. Di Lorenzo G, Tortora G, D'Armiento FP, De Rosa G, Staibano S, Autorino R, D'Armiento M, De Laurentiis M, De Placido S, Catalano G, Bianco AR, Ciardiello F. Expression of epidermal growth factor receptor correlates with disease relapse and progression to androgenindependence in human prostate cancer. Clin Cancer Res. 2002; 8:3438-3444.

97. Mendelsohn J, Baselga J. The EGF receptor family as targets for cancer therapy. Oncogene. 2000; 19:6550-6565.

98. Wang Y, Lin Z, Sun L, Fan S, Huang Z, Zhang D, Yang Z,

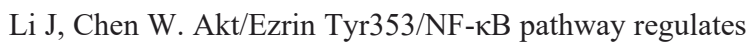
EGF-induced EMT and metastasis in tongue squamous cell carcinoma. Br J Cancer. 2014; 110:695-705.

99. Ha GH, Kim JL, Breuer EKY. TACC3 Is Essential for
EGF-Mediated EMT in Cervical Cancer. PLoS One. 2013; 8:e70353.

100. Zuo JH, Zhu W, Li MY, Li XH, Yi H, Zeng GQ, Wan XX, He QY, Li JH, Qu JQ, Chen Y and Xiao ZQ. Activation of EGFR promotes squamous carcinoma SCC10A cell migration and invasion via inducing EMT-like phenotype change and MMP-9-mediated degradation of E-cadherin. J Cell Biochem. 2011; 112: 2508-2517.

101. Lu X, Kang Y. Epidermal growth factor signalling and bone metastasis. Br J Cancer. 2010; 102:457-461.

102. Lee MY, Chou CY, Tang MJ, Shen MR. Epithelialmesenchymal transition in cervical cancer: correlation with tumor progression, epidermal growth factor receptor overexpression, and snail up-regulation. Clin Cancer Res. 2008; 14:4743-4750.

103. Liu ZC, Chen XH, Song HX, Wang HS, Zhang G, Wang H, Chen DY, Fang R, Liu H, Cai SH, Du J. Snail regulated by $\mathrm{PKC} / \mathrm{GSK}-3 \beta$ pathway is crucial for EGF-induced epithelial-mesenchymal transition (EMT) of cancer cells. Cell Tissue Res. 2014; 358:491-502.

104. Cross DA, Alessi DR, Cohen P, Andjelkovich M, Hemmings BA. Inhibition of glycogen synthase kinase-3 by insulin mediated by protein kinase B. Nature. 1995; 378:785-789.

105. Gan Y, Shi C, Inge L, Hibner M, Balducci J, Huang Y. Differential roles of ERK and Akt pathways in regulation of EGFR-mediated signaling and motility in prostate cancer cells. Oncogene. 2010; 29:4947-4958.

106. Karantanos T, Corn PG, Thompson TC. Prostate cancer progression after androgen deprivation therapy: mechanisms of castrate-resistance and novel therapeutic approaches. Oncogene. 2013; 32:5501-5511.

107. Cordonnier T, Bishop JL, Shiota M, Nip KM, Thaper D, Vahid S, Heroux D, Gleave M, Zoubeidi A. Hsp27 regulates $\mathrm{EGF} / \beta$-catenin mediated epithelial to mesenchymal transition in prostate cancer. Int J Cancer. 2015; 136:E496E507.

108. Lianos GD, Alexiou GA, Mangano A, Mangano A, Rausei $\mathrm{S}$, Boni L, Dionigi G, Roukos DH. The role of heat shock proteins in cancer. Cancer Lett. 2015; 360:114-118.

109. Cornford PA, Dodson AR, Parsons KF, Desmond AD, Woolfenden A, Fordham M, Neoptolemos JP, Ke Y, Foster CS. Heat shock protein expression independently predicts clinical outcome in prostate cancer. Cancer Res. 2000; 60:7099-7105.

110. Voll EA, Ogden IM, Pavese JM, Huang X, Xu L, Jovanovic $\mathrm{BD}$, Bergan RC. Heat shock protein 27 regulates human prostate cancer cell motility and metastatic progression. Oncotarget. 2014; 5:2648-2663. doi: 10.18632/ oncotarget.1917.

111. Foster CS, Dodson AR, Ambroisine L, Fisher G, Møller H, Clark J, Attard G, De-Bono J, Scardino P, Reuter VE, Cooper CS, Berney DM, Cuzick J. Hsp-27 expression at diagnosis predicts poor clinical outcome in prostate cancer 
independent of ETS-gene rearrangement. $\mathrm{Br} \mathrm{J}$ Cancer. 2009; 101:1137-1144.

112. Rocchi P, Beraldi E, Ettinger S, Fazli L, Vessella RL, Nelson C, Gleave M. Increased Hsp27 after androgen ablation facilitates androgen-independent progression in prostate cancer via signal transducers and activators of transcription 3-mediated suppression of apoptosis. Cancer Res. 2005; 65:11083-11093.

113. Shiota M, Itsumi M, Takeuchi A, Imada K, Yokomizo A, Kuruma H, Inokuchi J, Tatsugami K, Uchiumi T, Oda Y, Naito S. Crosstalk between epithelial-mesenchymal transition and castration resistance mediated by Twist1/AR signaling in prostate cancer. Endocr Relat Cancer. 2015; 22:889-900.

114. Cho KH, Choi MJ, Jeong KJ, Kim JJ, Hwang MH, Shin SC, Park CG, Lee HY. A ROS/STAT3/HIF-1 $\alpha$ signaling cascade mediates EGF-induced TWIST1 expression and prostate cancer cell invasion. Prostate. 2014; 74:528-536.

115. Yang J, Mani SA, Donaher JL, Ramaswamy S, Itzykson RA, Come C, Savagner P, Gitelman I, Richardson A, Weinberg RA. Twist, a master regulator of morphogenesis, plays an essential role in tumor metastasis. Cell. 2004; 117:927-939.

116. Kao CJ, Martiniez A, Shi XB, Yang J, Evans CP, Dobi A, deVere White RW, Kung HJ. miR-30 as a tumor suppressor connects EGF/Src signal to ERG and EMT. Oncogene. 2014; 33:2495-2503.

117. Tomlins SA, Laxman B, Varambally S, Cao X, Yu J, Helgeson BE, Cao Q, Prensner JR, Rubin MA, Shah RB, Mehra R, Chinnaiyan AM. Role of the TMPRSS2-ERG Gene Fusion in Prostate Cancer. Neoplasia. 2008; 10:177188.

118. Leshem O, Madar S, Kogan-Sakin I, Kamer I, Goldstein I, Brosh R, Cohen Y, Jacob-Hirsch J, Ehrlich M, Ben-Sasson S, Goldfinger N, Loewenthal R, Gazit E, et al. TMPRSS2/ ERG Promotes Epithelial to Mesenchymal Transition through the ZEB1/ZEB2 Axis in a Prostate Cancer Model. PLoS One. 2011; 6:e21650.

119. Sun C, Dobi A, Mohamed A, Li H, Thangapazham RL, Furusato B, Shaheduzzaman S, Tan SH, Vaidyanathan G, Whitman E, Hawksworth DJ, Chen Y, Nau M, et al. TMPRSS2-ERG fusion, a common genomic alteration in prostate cancer activates C-MYC and abrogates prostate epithelial differentiation. Oncogene. 2008; 27:5348-5353.

120. King JC, Xu J, Wongvipat J, Hieronymus H, Carver BS, Leung DH, Taylor BS, Sander C, Cardiff RD, Couto SS, Gerald WL, Sawyers CL. Cooperativity of TMPRSS2-ERG with PI3-kinase pathway activation in prostate oncogenesis. Nat Genet. 2009; 41:524-526.

121. Petrovics G, Liu A, Shaheduzzaman S, Furusato B, Sun C, Chen Y, Nau M, Ravindranath L, Chen Y, Dobi A, Srikantan V, Sesterhenn IA, McLeod DG, et al. Frequent overexpression of ETS-related gene-1 (ERG1) in prostate cancer transcriptome. Oncogene. 2005; 24:3847-3852.
122. Tomlins SA, Rhodes DR, Perner S, Dhanasekaran SM, Mehra R, Sun XW, Varambally S, Cao X, Tchinda J, Kuefer R, Lee C, Montie JE, Shah RB, et al. Recurrent fusion of TMPRSS2 and ETS transcription factor genes in prostate cancer. Science. 2005; 310:644-648.

123. Mani SA, Guo W, Liao MJ, Eaton EN, Ayyanan A, Zhou AY, Brooks M, Reinhard F, Zhang CC, Shipitsin M, Campbell LL, Polyak K, Brisken C, et al. The epithelialmesenchymal transition generates cells with properties of stem cells. Cell. 2008; 133:704-715.

124. Pirozzi G, Tirino V, Camerlingo R, Franco R, La Rocca A, Liguori E, Martucci N, Paino F, Normanno N, Rocco G. Epithelial to Mesenchymal Transition by TGF $\beta$-1 Induction Increases Stemness Characteristics in Primary Non Small Cell Lung Cancer Cell Line. PLoS ONE. 2011; 6:e21548.

125. Bisson I, Prowse DM. WNT signaling regulates selfrenewal and differentiation of prostate cancer cells with stem cell characteristics. Cell Res. 2009; 19:683-697.

126. Ruscetti M, Quach B, Dadashian EL, Mulholland DJ, Wu H. Tracking and Functional Characterization of EpithelialMesenchymal Transition and Mesenchymal Tumor Cells During Prostate Cancer Metastasis. Cancer Res. 2015; 75:2749-2759.

127. Seiler D, Zheng J, Liu G, Wang S, Yamashiro J, Reiter RE, Huang J, Zeng G. Enrichment of putative prostate cancer stem cells after androgen deprivation: upregulation of pluripotency transactivators concurs with resistance to androgen deprivation in LNCaP cell lines. Prostate. 2013; 73:1378-1390.

128. Luo Y, Cui X, Zhao J, Han Y, Li M, Lin Y, Jiang Y, Lan L. Cells susceptible to epithelial-mesenchymal transition are enriched in stem-like side population cells from prostate cancer. Oncol Rep. 2014; 31:874-884.

129. Dubrovska A, Kim S, Salamone RJ, Walker JR, Maira SM, García-Echeverría C, Schultz PG, Reddy VA. The role of PTEN/Akt/PI3K signaling in the maintenance and viability of prostate cancer stem-like cell populations. Proc Natl Acad Sci USA. 2009; 106:268-273.

130. Gu L, Vogiatzi P, Puhr M, Dagvadorj A, Lutz J, Ryder A, Addya S, Fortina P, Cooper C, Leiby B, Dasgupta A, Hyslop T, Bubendorf L, et al. Stat5 promotes metastatic behavior of human prostate cancer cells in vitro and in vivo. Endocr Relat Cancer. 2010; 17:481-493.

131. Nam EH, Lee Y, Moon B, Lee JW, Kim S. Twist1 and AP-1 cooperatively upregulate integrin $\alpha 5$ expression to induce invasion and the epithelial-mesenchymal transition. Carcinogenesis. 2015; 36:327-337.

132. Jung HY, Yang J. Unraveling the TWIST between EMT and cancer stemness. Cell Stem Cell. 2015; 16:1-2.

133. Chang L, Graham PH, Hao J, Ni J, Bucci J, Cozzi PJ, Kearsley JH, Li Y. Acquisition of epithelial-mesenchymal transition and cancer stem cell phenotypes is associated with activation of the $\mathrm{PI} 3 \mathrm{~K} / \mathrm{Akt} / \mathrm{mTOR}$ pathway in prostate cancer radioresistance. Cell Death Dis. 2013; 4:e875. 
134. Zhifang M, Liang W, Wei Z, Bin H, Rui T, Nan W, Shuhai $Z$. The androgen receptor plays a suppressive role in epithelial-mesenchymal transition of human prostate cancer stem progenitor cells. BMC Biochem. 2015; 16:13.

135. Liu C, Kelnar K, Liu B, Chen X, Calhoun-Davis T, Li H, Patrawala L, Yan H, Jeter C, Honorio S, Wiggins JF, Bader AG, Fagin R, et al. Identification of miR-34a as a potent inhibitor of prostate cancer progenitor cells and metastasis by directly repressing CD44. Nat Med. 2011; 17:211-215.

136. Xu H, Tian Y, Yuan X, Wu H, Liu Q, Pestell RG, Wu K. The role of CD44 in epithelial-mesenchymal transition and cancer development. Onco Targets Ther. 2015; 8:37833792 .

137. Shang Z, Cai Q, Zhang M, Zhu S, Ma Y, Sun L, Jiang N, Tian J, Niu X, Chen J, Sun Y, Niu Y. A switch from CD44+ cell to EMT cell drives the metastasis of prostate cancer. Oncotarget. 2015; 6:1202-1216. doi: 10.18632/ oncotarget.2841.

138. Wang M, Ren D, Guo W, Huang S, Wang Z, Li Q, Du $\mathrm{H}$, Song L, Peng X. N-cadherin promotes epithelialmesenchymal transition and cancer stem cell-like traits via ErbB signaling in prostate cancer cells. Int J Oncol. 2016; 48:595-606.

139. Li P, Yang R, Gao WQ. Contributions of epithelialmesenchymal transition and cancer stem cells to the development of castration resistance of prostate cancer. Mol Cancer. 2014; 13:55.

140. Murali AK, Norris JS. Differential expression of epithelial and mesenchymal proteins in a panel of prostate cancer cell lines. J Urol. 2012; 188:632-638.

141. Armstrong AJ, Healy P, Halabi S, Vollmer R, Lark A, Kemeny G, Ware K, Freedland SJ. Evaluation of an epithelial plasticity biomarker panel in men with localized prostate cancer. Prostate Cancer Prostatic Dis. 2016; 19:4045 .

142. Gravdal K, Halvorsen OJ, Haukaas SA, Akslen LA. A switch from E-cadherin to $\mathrm{N}$-cadherin expression indicates epithelial to mesenchymal transition and is of strong and independent importance for the progress of prostate cancer. Clin Cancer Res. 2007; 13:7003-7011.

143. Ren D, Wang M, Guo W, Huang S, Wang Z, Zhao X, Du H, Song L, Peng X. Double-negative feedback loop between ZEB2 and miR-145 regulates epithelial-mesenchymal transition and stem cell properties in prostate cancer cells. Cell Tissue Res. 2014; 358:763-778.

144. Huang S, Guo W, Tang Y, Ren D, Zou X, Peng X. miR143 and miR-145 inhibit stem cell characteristics of PC-3 prostate cancer cells. Oncol Rep. 2012; 28:1831-1837.

145. Gao P, Xing AY, Zhou GY, Zhang TG, Zhang JP, Gao C, Li H, Shi DB. The molecular mechanism of microRNA-145 to suppress invasion-metastasis cascade in gastric cancer. Oncogene. 2013; 32:491-501.

146. Ren D, Wang M, Guo W, Zhao X, Tu X, Huang S, Zou $\mathrm{X}$, Peng X. Wild-type p53 suppresses the epithelial- mesenchymal transition and stemness in PC-3 prostate cancer cells by modulating miR 145. Int J Oncol. 2013; 42:1473-1481.

147. Jiang YG, Luo Y, He DL, Li X, Zhang LL, Peng T, Li MC, Lin YH. Role of Wnt/beta-catenin signaling pathway in epithelial-mesenchymal transition of human prostate cancer induced by hypoxia-inducible factor-1alpha. Int $\mathrm{J}$ Urol. 2007; 14:1034-1039.

148. Hsieh IS, Chang KC, Tsai YT, Ke JY, Lu PJ, Lee KH, Yeh SD, Hong TM, Chen YL. MicroRNA-320 suppresses the stem cell-like characteristics of prostate cancer cells by downregulating the Wnt/beta-catenin signaling pathway. Carcinogenesis. 2013; 34:530-538.

149. Nanta R, Kumar D, Meeker D, Rodova M, Van Veldhuizen PJ, Shankar S, Srivastava RK. NVP-LDE-225 (Erismodegib) inhibits epithelial-mesenchymal transition and human prostate cancer stem cell growth in NOD/SCID IL2R $\gamma$ null mice by regulating Bmi-1 and microRNA-128. Oncogenesis. 2013; 2:e42.

150. Kojima S, Goto Y, Naya Y. The roles of microRNAs in the progression of castration-resistant prostate cancer. J Hum Genet. 2017; 62:25-31.

151. Rea D, Del Vecchio V, Palma G, Barbieri A, Falco M, Luciano A, De Biase D, Perdonà S, Facchini G, Arra C. Mouse Models in Prostate Cancer Translational Research: From Xenograft to PDX. Biomed Res Int. 2016; 2016:9750795.

152. Sun T, Yang M, Kantoff P, Lee GS. Role of microRNA-221/-222 in cancer development and progression. Cell Cycle. 2009; 8:2315-2316.

153. DeVere White RW, Vinall RL, Tepper CG, Shi XB. MicroRNAs and their Potential for Translation in Prostate Cancer. Urol Oncol. 2009; 27:307-311.

154. Nguyen HC, Xie W, Yang M, Hsieh CL, Drouin S, Lee GS, Kantoff PW. Expression differences of circulating microRNAs in metastatic castration resistant prostate cancer and low-risk, localized prostate cancer. Prostate. 2013; 73:346-354.

155. Sekhon K, Bucay N, Majid S, Dahiya R, Saini S. MicroRNAs and epithelial-mesenchymal transition in prostate cancer. Oncotarget. 2016; 7:67597-67611. doi: 10.18632/oncotarget.11708.

156. Boccellino M, Alaia C, Misso G, Cossu AM, Facchini G, Piscitelli R, Quagliuolo L, Caraglia M. Gene interference strategies as a new tool for the treatment of prostate cancer. Endocrine. 2015; 49:588-605.

157. Della Pepa C, D'Aniello C, Rossetti S, Iovane G, Pisconti S, Fisichella R, Facchini G, Cavaliere C. "Real-life" effectiveness studies in mCRPC patients: systematic review. WCRJ. 2015; 2:e617. 